AGH DRILLING, OIL, GAS • Vol. 32 • No. $2 \cdot 2015$

http://dx.doi.org/10.7494/drill.2015.32.2.381

\author{
Ján Pinka*, Lucia Kucirková*
}

\title{
THE IMPORTANCE OF THE FORMATION \\ AND FRACTURE PRESSURES \\ FOR THE SELECTION OF THE DEPTHS \\ FOR CASING SETTING IN SLOVAKIA
}

\section{INTRODUCTION}

The processes of well drilling are carried out in rocks formation with different lithological composition, physical and mechanical properties, the degree of saturation and the fluid type. These rocks lie in layers with pressures that are lower than normal pressure or in layers with anomalous pressure. Sedimentary rocks - the common rock types in drilling of hydrocarbons - are usually unstable, either by pressure of overburden or by treatment of drilling fluid/mud.

The primary stage of well design is determination of the borehole structure, that is to say the determination of the number of casing strings, casing depths, diameters of drill bits and conditions of the cementation. Thus, the selection of the borehole structure is in regard to drilling conditions, the level of the equipment and technologies used in drilling, the possibility of quick and smooth disposal of difficulties and accidents, but also the borehole structure must meet the desired objectives and must be economical. For this purpose, it is necessary to determine the maximum of geological and other data, at least two, namely: formation pressure (pore pressure) and fracture pressure depending on the depth. In addition to the basis of program for casing, both parameters are important for cementation and subsequently for stimulation during the extraction and the like.

The condition for the successful drilling is that the density of drilling fluid and also the hydrostatic pressure are slightly higher than the formation pressure. This condition can be very clearly documented via dependence of equivalent density or density of drilling fluid with wellbore depth, expressed graphically in Figure 1. We can move in the workspace

\footnotetext{
* The Technical University of Košice, Faculty of Mining, Ecology, Process Control and Geotechnology
} 
which is to the right of the indicated curve that limits the possibility of blowout. The working surface is also bounded on the other side by the fracture pressure equivalent density curve with wellbore depth that may cause loss of drilling fluid.

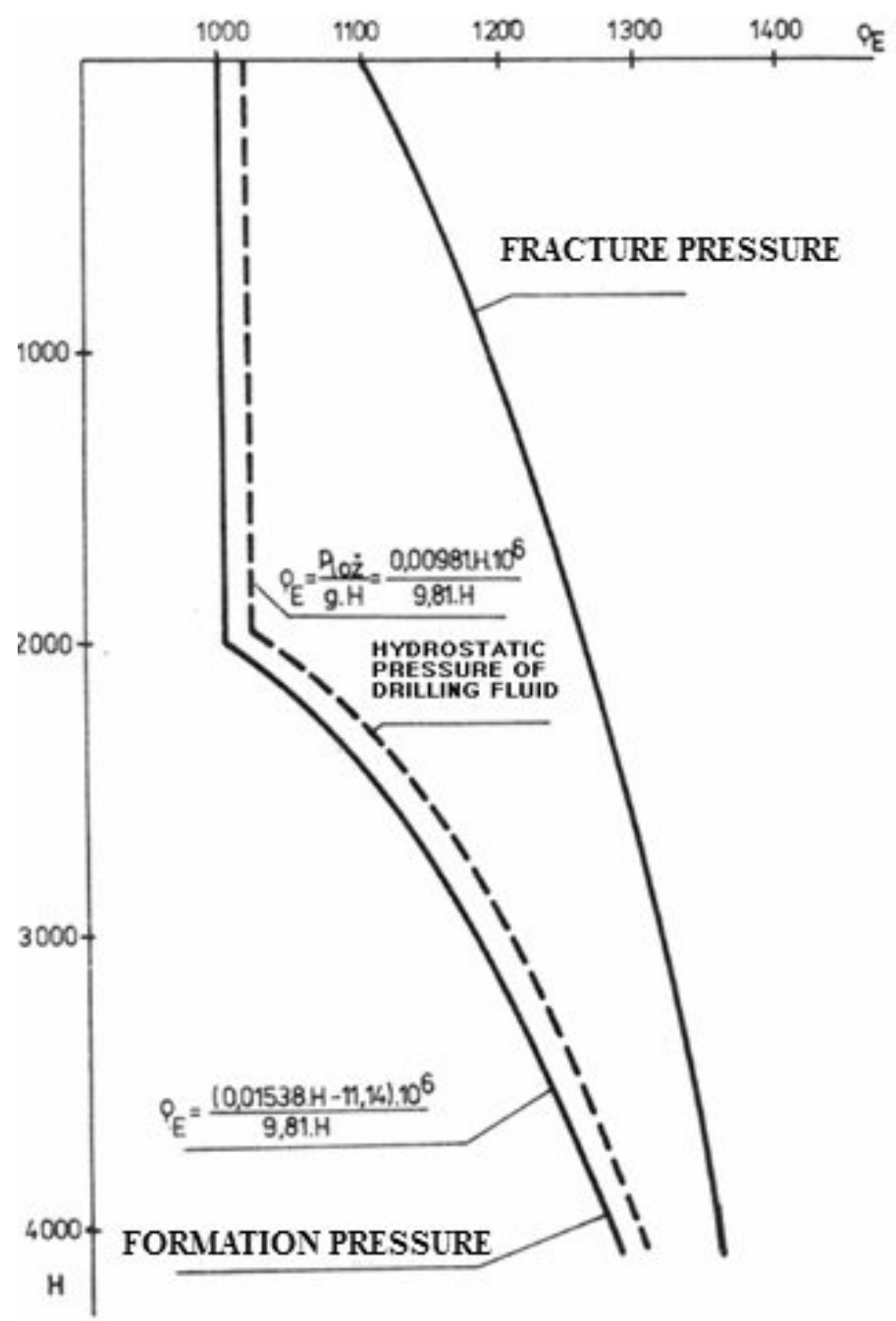

Fig. 1. The relationship between the wellbore depth $H[\mathrm{~m}]$ and the equivalent density of drilling fluid $Q_{E}\left[\mathrm{~kg} \cdot \mathrm{m}^{-3}\right]$

\section{FRACTURE PRESSURE}

The fracture pressure limits the upper bound of the pressures in the borehole. Rocks resistance to leakage of fluid in open borehole is a function of the rock strength, its litholo- 
gy, the geological age, the borehole depth and the overall state of in-situ stresses within the rock mass. Our aim in this article is to determine the natural state of stresses by means of artificially increasing the local stresses and subsequently to observe the changes that occurred. This method is used in determining of fracture pressures below the casing shoe.

The overall state of stresses in rocks is characterized by three principal stresses, which are unequal in size. The fracture pressure must be approximately equal to the smallest value of these three stresses. The leak-off test pressures are shown in Figure 2.

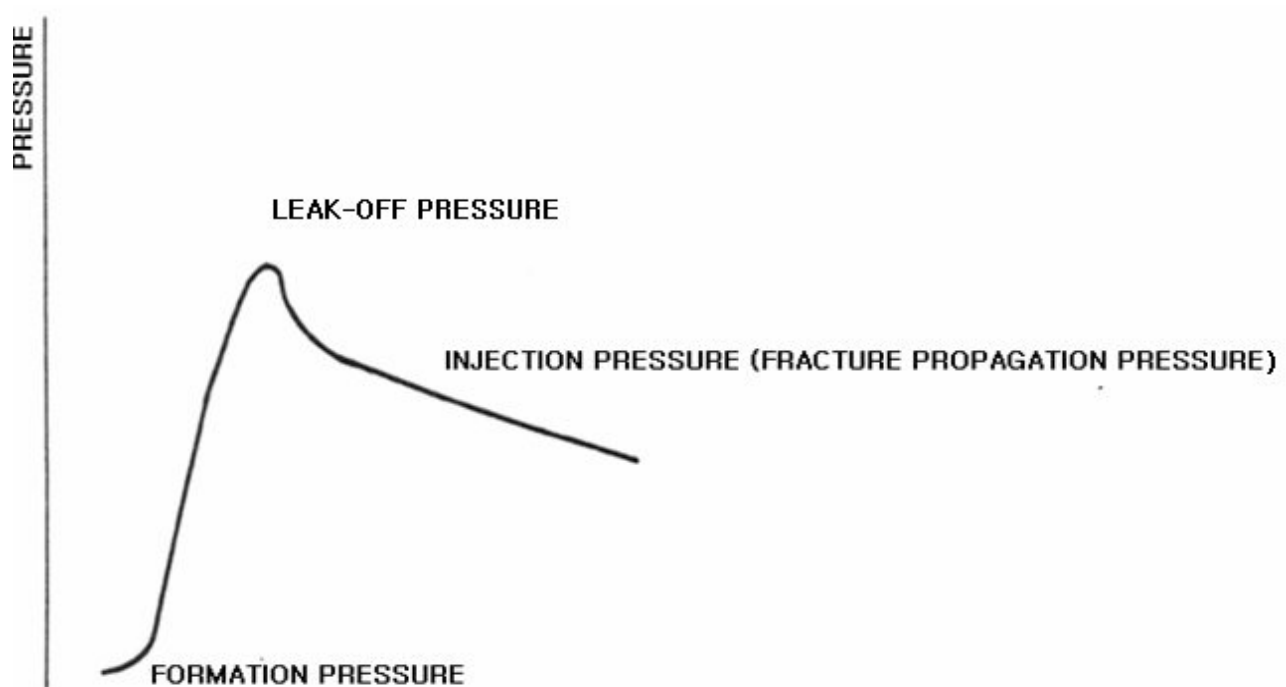

TIME PUMPED (VOLUME PUMPED)

Fig. 2. Schematic representation of pressure during leak-off test depending on the pumping volume (pumping time)

Detection of fracture pressures is an important technological operation and the procedure to determine fracture pressures is processed in the operating rules [3]. The design process doesn't require specific borehole data, for approximate determination of fracture pressure values is used one of the recommended methods, e.g. Hubbert and Willis method, Matthews and Kelly method or Eaton's method [5].

\section{THE PRINCIPLE OF DESIGN SETTING DEPTH OF CASING STRINGS}

The method for determining the casing depth of casing strings is explained in graphic record of the formation and fracture pressure trends with wellbore depth (Fig. 3). For simplification, it is assumed that the hydrostatic pressure of drilling fluid is equal to 
the formation pressure. The planned borehole should be cased to the depth $H_{1}$, using the production casing string. To allow drilling at indicated depth is possible, provided that the drilling fluid has a minimum density $H_{1,2}$, to eliminate the formation pressure effect at that depth. This drilling fluid density allows drilling at depths greater that $H_{2,3}$, because at depths less than $H_{2,3}$, without casing the intermediate casing string there is a possibility of fracturing the rocks. As drilling progresses from top to bottom, the drilling fluid density at depths $H_{2,3}$ can be equal to the max value $\rho_{3,4}$. As before, $\rho_{3,4}$ density is determined by the depth of further intermediate casing string $H_{4,5}$. From this procedure also it follows a principled method for determining the borehole structure - casing programme, as shown in Figure 3.

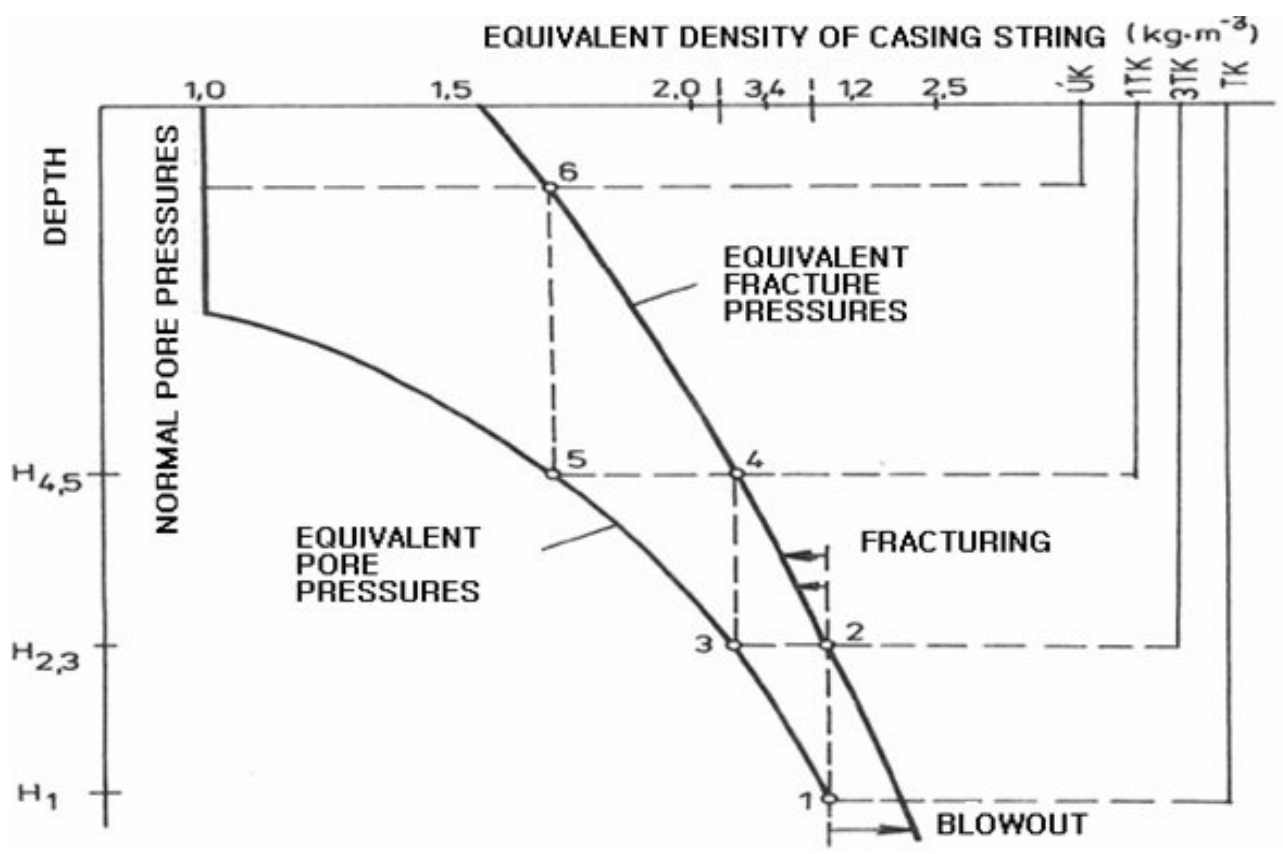

Fig. 3. Method for determining the casing depth of casing strings

The correct choice of designing the casing setting, depending on the borehole depth with equivalent drilling fluid density should thus be placed on the area between the formation pressure (pore pressure) curve and the fracture pressures curve (Fig. 3). Therefore, it is more correct and precise to say - between the safety margins of fracture pressure and pore pressure (Fig. 4). On the right of the figure, after exceeding the fracture pressure values there is the risk of lost circulation of drilling fluid. Also, in case of lower well pressure (e.g. low density of drilling fluid) than the pore pressure (on the left), there is the risk of blowouts/kicks (Fig. 5). 


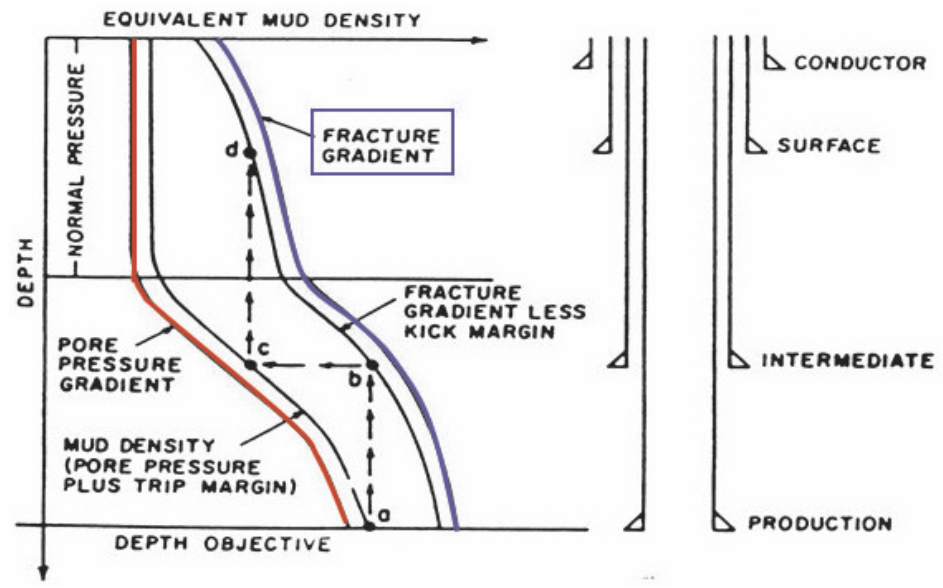

Fig. 4. The selection of depth for casing setting should proceed from bottom to top (gradually through the points: $\mathrm{a}$ - production casing, $\mathrm{b}$ - intermediate casing, $\mathrm{c}$ - surface casing, $\mathrm{d}$ - conductor casing). Thus, between the pore pressure curve (formation pressure + margin of formation pressure) and the fracture pressures curve (+ margin of fracture pressure)

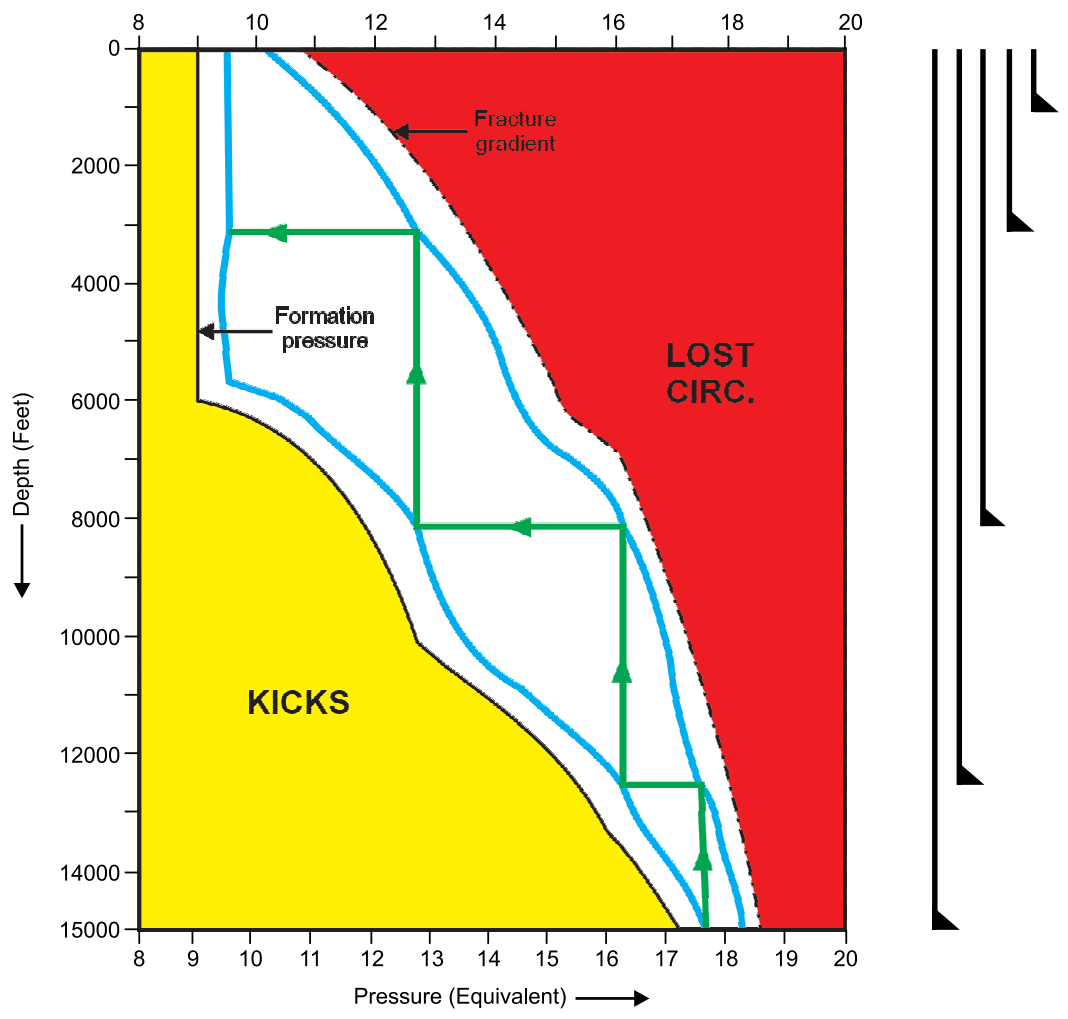

Fig. 5. The suitability of depth for casing setting (marked with a green line) 


\section{THE DETERMINATION OF FRACTURE PRESSURES OF THE VIENNA BASIN}

The Slovak Republic's natural gas is located and also extracted in two regions, i.e. in the Vienna Basin area and in the East Slovakian Neogene Basin, where the geological exploration is currently taking place. In both areas, the fracture pressure values of some wells have been calculated and observed, as well as, the casing depth depending on equivalent mud density. The values of the Vienna Basin wells are listed in Table 1 and the graphical representations of cased boreholes are shown in Figures 6, 7,8 and 9.

Table 1

The fracture pressures calculated values (observed values) of the Vienna Basin wells

\begin{tabular}{|c|c|c|c|c|c|c|}
\hline 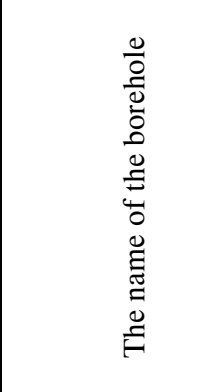 & 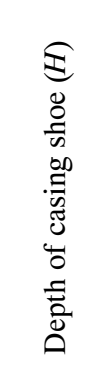 & 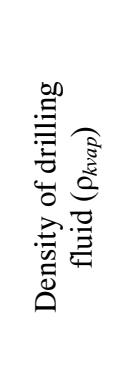 & 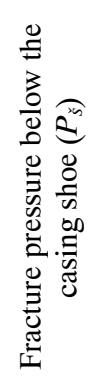 & 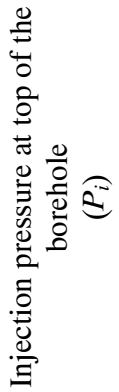 & 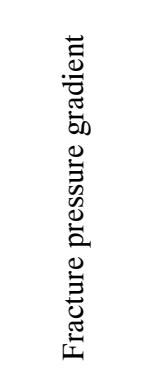 & 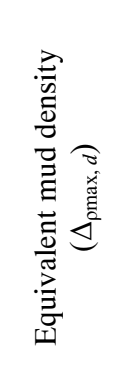 \\
\hline & {$[\mathrm{m}]$} & {$\left[\mathrm{kg} \cdot \mathrm{m}^{-3}\right]$} & {$[\mathrm{MPa}]$} & [MPa] & {$\left[\mathrm{kPa} \cdot \mathrm{m}^{-1}\right]$} & {$\left[\mathrm{kg} \cdot \mathrm{m}^{-3}\right]$} \\
\hline Malacky Z 102 & 155.98 & 1120 & 3.108 & 1.440 & 19.926 & 2031 \\
\hline Suchohrad 64 & 197.52 & 1150 & 3.771 & 1.650 & 19.092 & 1946 \\
\hline Jakubov 70 & 298.88 & 1130 & 6.287 & 3.141 & 21.035 & 2144 \\
\hline Jakubov 73 & 300.07 & 1125 & 6.410 & 3.167 & 21.362 & 2178 \\
\hline Jakubov 71 & 302.02 & 1120 & 6.802 & 3.610 & 22.522 & 2296 \\
\hline Jakubov 72 & 305.11 & 1110 & 7.181 & 4.000 & 23.536 & 2399 \\
\hline Jakubov 67 & 350.42 & 1130 & 7.504 & 3.700 & 21.414 & 2183 \\
\hline Jakubov 66 & 351.33 & 1130 & 7.524 & 3.500 & 21.416 & 2183 \\
\hline Jakubov 69 & 354.41 & 1130 & 8.287 & 4.550 & 23.383 & 2384 \\
\hline Gajary 148 & 354.52 & 1145 & 7.022 & 3.130 & 19.807 & 2019 \\
\hline Suchohrad 66 & 354.70 & 1120 & 7.287 & 3.543 & 20.544 & 2094 \\
\hline Gajary 134 & 375.02 & 1120 & 8.711 & 4.665 & 23.228 & 2368 \\
\hline Gajary 133 & 375.06 & 1130 & 7.587 & 3.500 & 20.229 & 2062 \\
\hline Gajary 132 & 384.98 & 1150 & 9.338 & 4.800 & 24.256 & 2473 \\
\hline Gajary 136 & 388.00 & 1140 & 8.884 & 4.600 & 22.897 & 2334 \\
\hline Gajary 139 & 388.48 & 1120 & 8.075 & 3.896 & 20.786 & 2119 \\
\hline
\end{tabular}


Table 1 cont.

\begin{tabular}{|l|c|c|c|c|c|c|}
\hline Záhorská Ves 5 & 391.98 & 1100 & 8.452 & 4.380 & 21.562 & 2198 \\
\hline Vysoká 37 & 398.51 & 1080 & 8.439 & 4.387 & 21.176 & 2159 \\
\hline Dúbrava 52 & 399.44 & 1125 & 8.549 & 4.327 & 21.402 & 2182 \\
\hline Dúbrava 50 & 399.87 & 1140 & 10.689 & 6.330 & 26.731 & 2725 \\
\hline Záhorská Ves 3 & 400.00 & 1140 & 7.667 & 3.310 & 19.168 & 1954 \\
\hline Vysoká 36 & 400.05 & 1100 & 8.829 & 4.600 & 22.070 & 2250 \\
\hline Jakubov 65 & 430.00 & 1165 & 9.194 & 4.300 & 21.381 & 2180 \\
\hline Láb 134 & 450.07 & 1120 & 7.825 & 3.100 & 17.386 & 1772 \\
\hline Gajary 147 & 458.50 & 1120 & 11.940 & 6.500 & 26.041 & 2655 \\
\hline Jakubov 68 & 461.19 & 1120 & 10.650 & 5.860 & 23.092 & 2354 \\
\hline Závod 95 & 498.44 & 1120 & 10.398 & 4.510 & 20.861 & 2127 \\
\hline Gajary 148 & 647.43 & 1085 & 12.724 & 5.840 & 18.866 & 1923 \\
\hline Jakubov 73 & 689.83 & 1115 & 12.171 & 4.938 & 17.643 & 1799 \\
\hline Malacky Z 102 & 699.86 & 1080 & 12.825 & 5.714 & 18.325 & 1868 \\
\hline Suchohrad 64 & 746.50 & 1115 & 14.337 & 6.633 & 19.206 & 1958 \\
\hline Gajary 136 & 791.72 & 1110 & 16.535 & 8.200 & 20.885 & 2129 \\
\hline Gajary 131 & 791.98 & 1115 & 13.154 & 4.850 & 16.609 & 1693 \\
\hline Gajary 133 & 793.44 & 1080 & 15.230 & 7.200 & 19.195 & 1957 \\
\hline Gajary 134 & 816.98 & 1090 & 13.795 & 5.683 & 16.885 & 1721 \\
\hline Gajary 139 & 818.02 & 1065 & 16.272 & 8.000 & 19.892 & 2028 \\
\hline
\end{tabular}

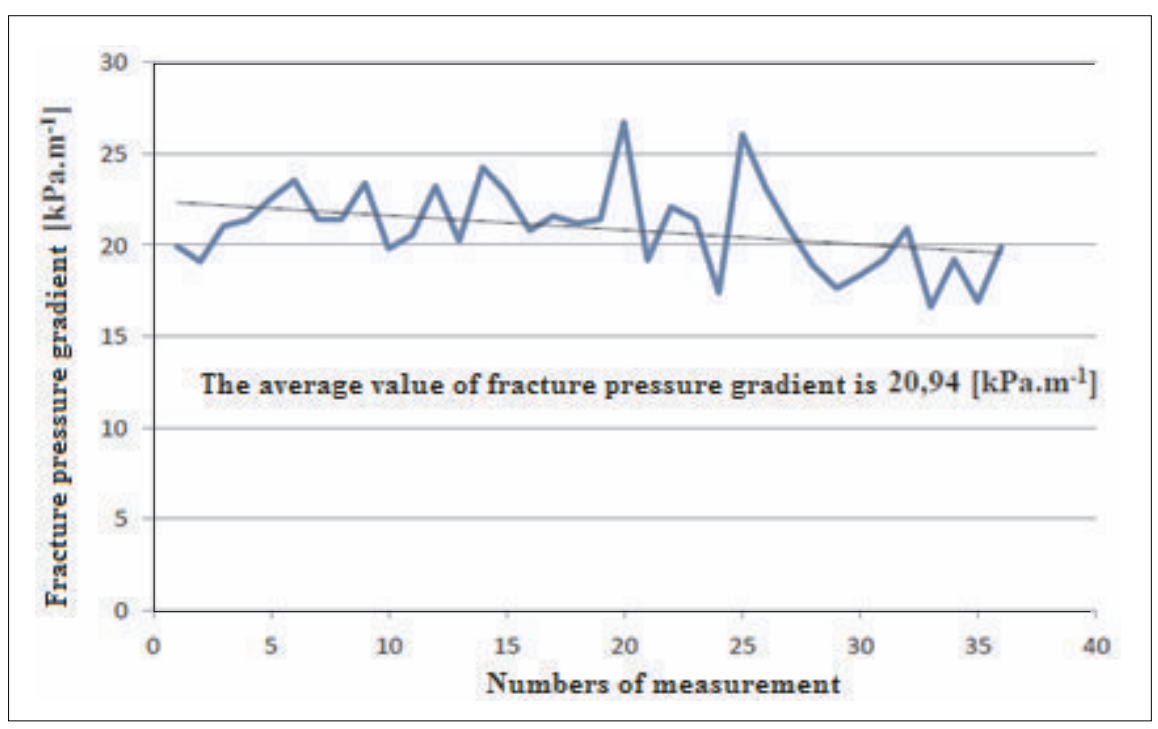

Fig. 6. The graph of fracture pressure gradient of in the Vienna Basin 


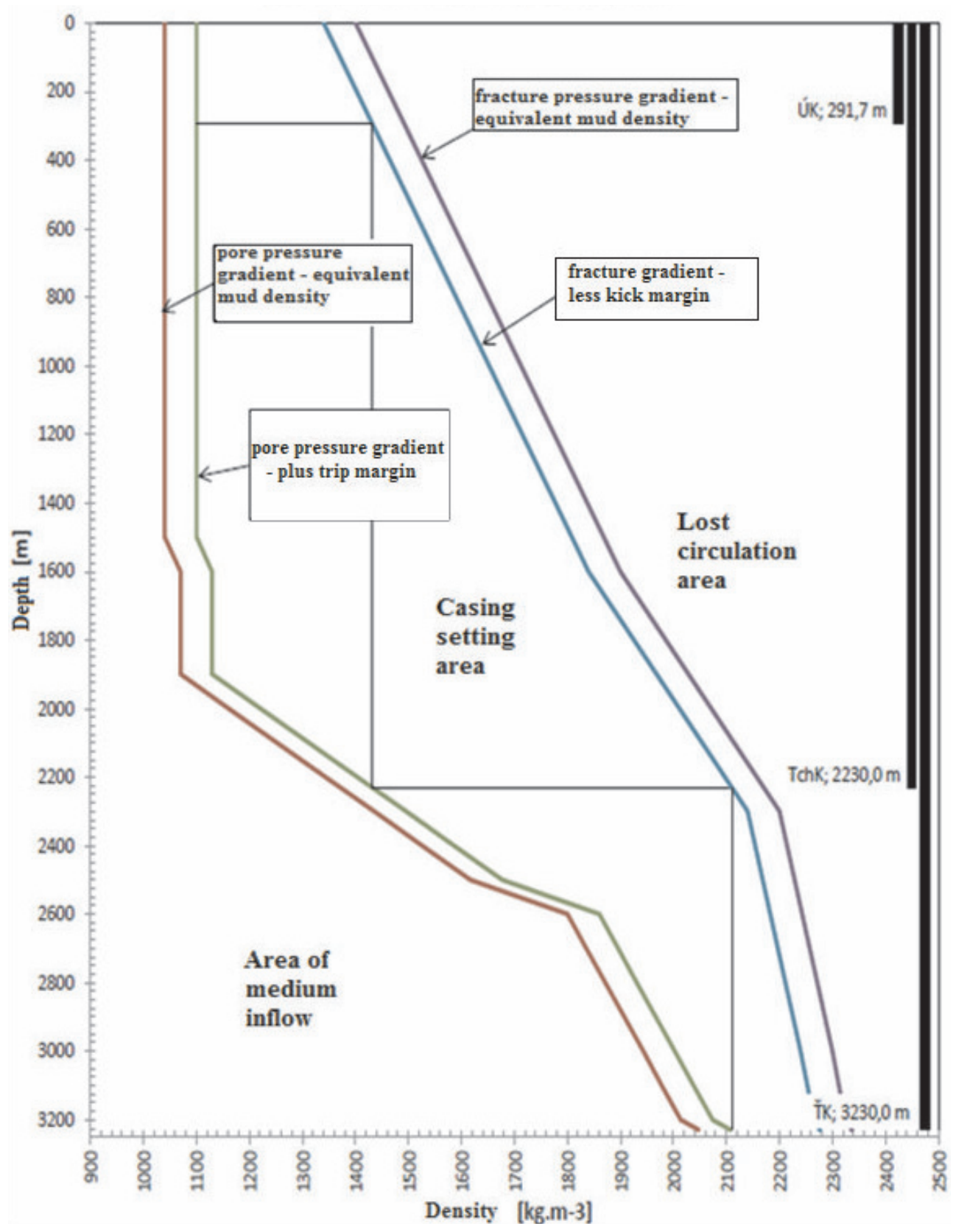

Fig. 7. The selection of depths for casing setting of gas deposit Kúty 


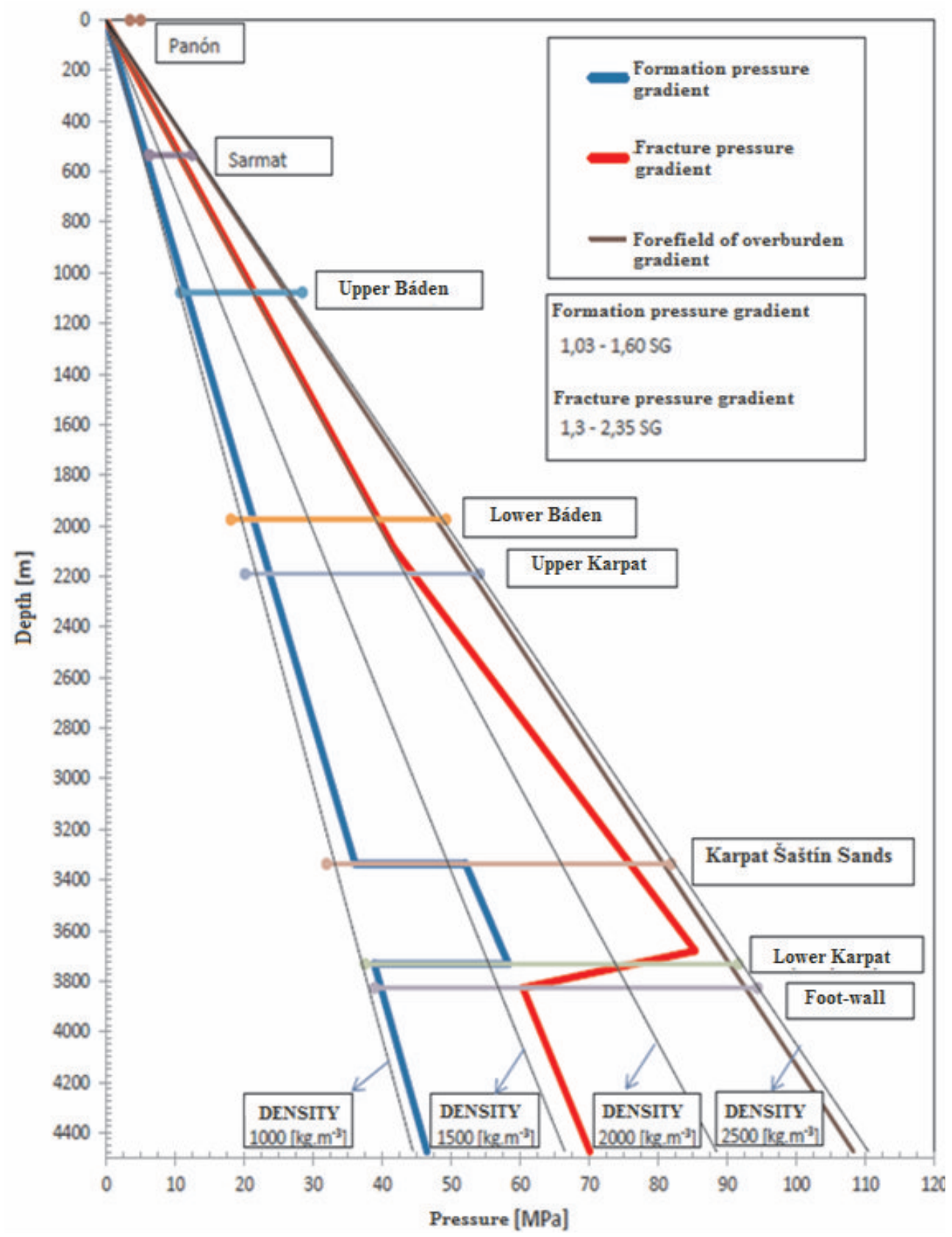

Fig. 8. Pressure conditions in the wellbore of gas deposit Závod 


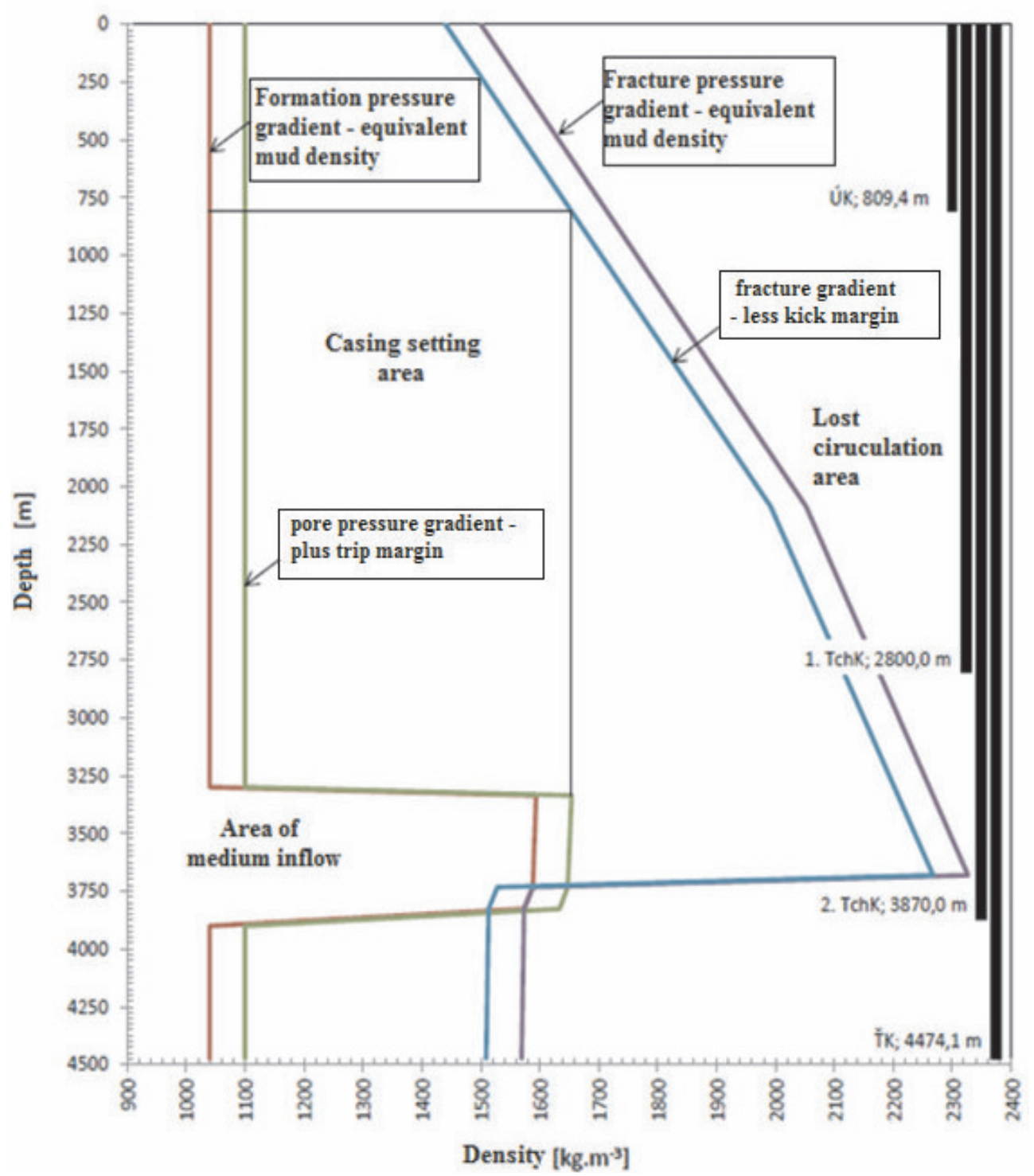

Fig. 9. The selection of depths for casing setting of gas deposit Závod

The formation pressures trend is slightly over-hydrostatic (see Fig. 9). The formation pressure gradient of the Šaštín sands is the single case, where this gradient is in the range of 1,6 SG. Below this interval, once again the formation pressure is slightly over-hydrostatic.

The determination of depths for casing setting according to this graphical method is not clear and the selection of casing setting depths is based on drilling parameters (length of open hole interval without casing). 


\section{THE DETERMINATION OF FRACTURE PRESSURES OF THE EAST SLOVAKIAN NEOGENE BASIN}

Also, the fracture pressure values of some wells in this area have been calculated and observed, as well as the casing depths of casing strings depending on the equivalent mud density and accordingly, the values for East Slovakian Neogene Basin wells. The calculated values are listed in Table 2 and the graphical representations of cased boreholes are in Figures 10 and 11.

Table 2

Fracture pressures calculated values of the East Slovakian Neogene Basin wells

\begin{tabular}{|c|c|c|c|c|c|c|}
\hline 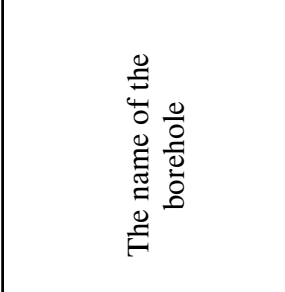 & 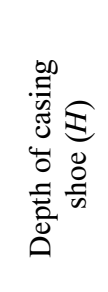 & 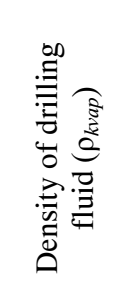 & 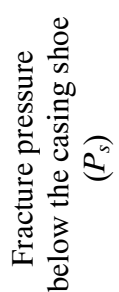 & 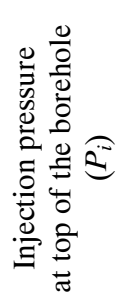 & 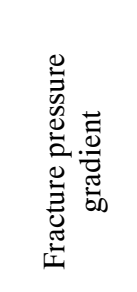 & 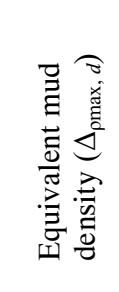 \\
\hline & {$[\mathrm{m}]$} & {$\left[\mathrm{kg} \cdot \mathrm{m}^{-3}\right]$} & {$[\mathrm{MPa}]$} & {$[\mathrm{MPa}]$} & {$\left[\mathrm{kPa} \cdot \mathrm{m}^{-1}\right]$} & {$\left[\mathrm{kg} \cdot \mathrm{m}^{-3}\right]$} \\
\hline Stretava 56 & 101.10 & 1210 & 2.035 & 0.810 & 20.129 & 2052 \\
\hline Zemplínska Široká 3 & 124.83 & 1180 & 2.970 & 1.500 & 23.792 & 2426 \\
\hline Bánovce 37 & 299.54 & 1110 & 6.077 & 2.960 & 20.288 & 2068 \\
\hline Pozdišovce 15 & 301.00 & 1180 & 6.653 & 3.200 & 22.103 & 2253 \\
\hline Michalovce 2 & 305.75 & 1150 & 6.666 & 3.380 & 21.802 & 2223 \\
\hline Moravany 1 & 309.61 & 1140 & 8.473 & 5.180 & 27.367 & 2790 \\
\hline Vrbnica 1 & 354.00 & 1180 & 7.094 & 3.110 & 20.040 & 2043 \\
\hline Vrbnica 2 & 361.00 & 1130 & 7.460 & 3.650 & 20.665 & 2107 \\
\hline Zemplínska Široká 1 & 393.36 & 1180 & 6.934 & 2.500 & 17.628 & 1797 \\
\hline Palín 1 & 398.50 & 1180 & 7.649 & 3.200 & 19.194 & 1957 \\
\hline Zemplínska Široká 6 & 437.74 & 1100 & 8.206 & 3.500 & 18.746 & 1911 \\
\hline Zemplínska Široká 2 & 448.15 & 1180 & 8.099 & 3.100 & 18.072 & 1842 \\
\hline
\end{tabular}


Table 2 cont.

\begin{tabular}{|c|c|c|c|c|c|c|}
\hline 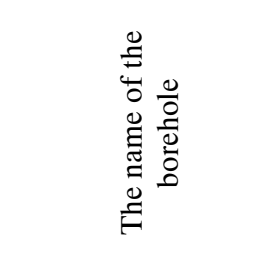 & 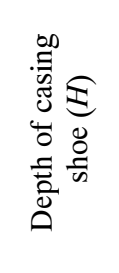 & 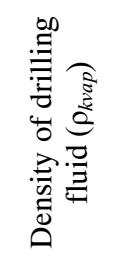 & 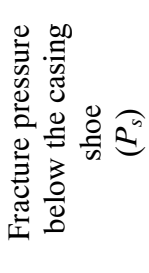 & 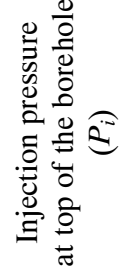 & 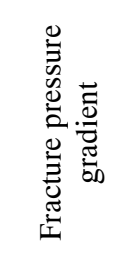 & 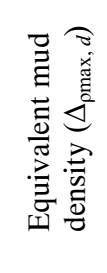 \\
\hline & [m] & {$\left[\mathrm{kg} \cdot \mathrm{m}^{-3}\right]$} & [MPa] & [MPa & {$\left[\mathrm{kPa} \cdot \mathrm{m}^{-1}\right]$} & {$\left[\mathrm{kg} \cdot \mathrm{m}^{-3}\right]$} \\
\hline Zemplínska Široká 4 & 449.33 & 1180 & 8.642 & 3.600 & 19.233 & 1961 \\
\hline Pavlovce 4 & 502.50 & 1180 & 7.458 & 3.600 & 14.842 & 1513 \\
\hline Sliepkovce 3 & 552.82 & 1190 & 10.216 & 4.000 & 18.480 & 1884 \\
\hline Stretava 56 & 800.00 & 1200 & 14.582 & 5.380 & 18.228 & 1858 \\
\hline Pozdišovce 15 & 1001.82 & 1150 & 22.194 & 11.300 & 22.154 & 2259 \\
\hline Zemplínska Široká 3 & 1006.59 & 1180 & 20.823 & 9.600 & 20.687 & 2109 \\
\hline Pavlovce 4 & 1712.00 & 1200 & 28.356 & unknown & 16.563 & 1688 \\
\hline
\end{tabular}

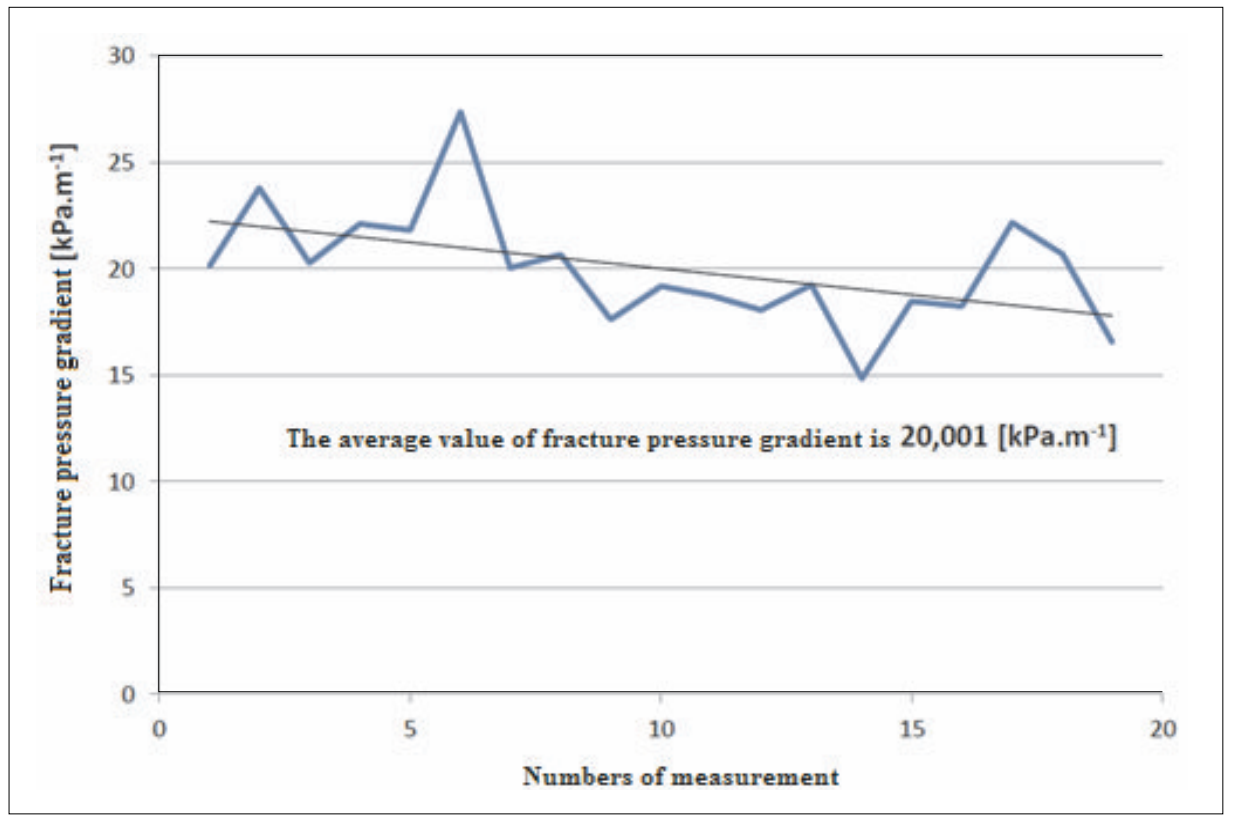

Fig. 10. The graph of fracture pressure gradient of the East Slovakian Neogene Basin 


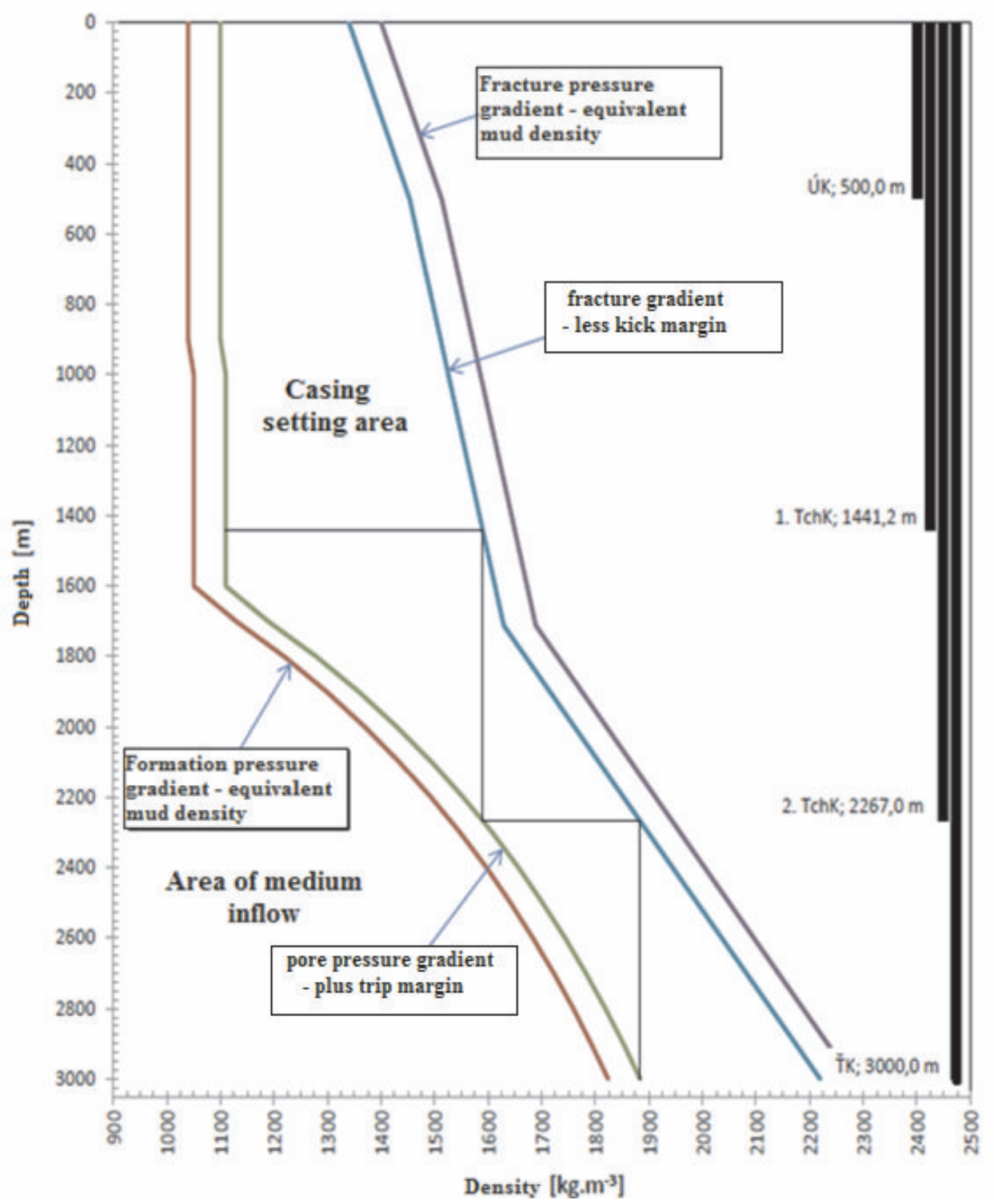

Fig. 11. The selection of depths for casing setting of gas deposit Pavlovce

\section{CONCLUSION}

Geological exploration for oil and gas is increasingly transferred to more challenging geological areas and environments. Therefore, the knowledge of pressure conditions during drilling operation is becoming a more and more important factor. Also, the knowledge 
and understanding of the principal stresses in wellbore are essential to wellbore stability problems. It is possible to obtain information about principal stresses during drilling by carrying out tightness tests of rock mass. These pressure testing systems, mainly Leak-Off Test (LOT) and Extended Leak-Off Test (ELOT) are carried out in the oil and gas industry for several decades. The obtained data are used to evaluate the pressure or strengths of rock mass, to verify the quality of cementation and also to estimate the magnitudes of principle stresses. This interpretation provides the basis for vital decisions, such as selection of depths for casing setting, the maximum permissible values of mud density, method of drilling and the tightness verification of cement and cementation work. Incorrect estimates can result not only in a increase the cost of the wellbores, but also can cause potentially hazardous situations, such as lost circulation of drilling fluid, problems with managing the boreholes, borehole stability problems and also blowouts. Therefore, the proper identification of principal stresses of wellbore will lead to reduction of non-productive time, as well as the cost-reduction in drilling operations and consequently to greater operational safety. Acquisition of fracture pressures in wellbores appears to be economic saving (The fracture pressures tests below the casing shoe are not required) and in the case, that the geological exploration is already carried out in the known geological area, in which the drilling activities were previously conducted. LOT (Leak-Off Test - the method for obtaining fracture pressures in wellbores) was also carried out in this area in the past.

\section{REFERENCES}

[1] Pinka J., Klempa M., Struna J.: Technika a technológie vrtných prací. I. díl. Marionetti Press, Ostrava 2014, 1-120, ISBN: 978-80-905737-0-3.

[2] Pinka J., Klempa M., Struna J.: Technika a technológie vrtných prací. II. díl. Marionetti Press, Ostrava 2014, 1-254, ISBN: 978-80-905737-1-0.

[3] Prevádzkový predpis č. 11/2010: Zistovanie štiepnych únikových tlakov vo vrte. NAFTA a.s., 2010.

[4] Švrček M.: Zistovanie a vyhodnocovanie únikových štiepnych tlakov v pôsobnosti Nafta a.s. Diplomová práca. F BERG TU Košice, 2014.

[5] Samudra A.B.: Fracture Pressure - Fracture Gradients. Halliburton, USA, 2011. Dostupné na internete: http://www.scribd.com/doc/55010634/Fracture-Pressure [cit. 2014.04.05].

[6] Strnište K., Šmolík S.: Hlbinné vŕtanie. 1. vyd. Alfa Bratislava, Bratislava 1992, 1-336, ISBN 80-05-01031-1. 